\title{
ANALYZING AN INFORMATION SYSTEMS PROGRAM SKILL-SET: A BOTTOM-UP VALIDATION OF A TOP-DOWN DESIGN
}

\author{
Arnaldo I. Ramos-Torres, University of Puerto Rico, arnaldo.ramos1@upr.edu \\ Maria del R. Rodriguez-Orellana,mrodriguezorellana@yahoo.com
}

\begin{abstract}
Information Systems programs are facing serious challenges. The source of many of these challenges is internal to these programs, therefore the solution lies within [12]. The continuous analysis and revision of the skills that IS programs are currently developing in students has a great potential to address the challenges [12]. This paper is the third of a trilogy on how to deal with the challenges currently faced by IS programs. It presents a methodology to analyze the skills these programs are developing in students, as well as its application to a particular case in order to determine the need to revise these skills. In the case presented, the methodology is used to determine if an existing program, originally designed using projects as the departing point, excludes, over-emphasizes or underemphasizes important skills. That is, we use the methodology to validate through a bottom-up (skill-based) approach a design originally performed using a top-down (project-based) approach.
\end{abstract}

Keywords: Information Systems (IS), IS Challenges, Project-Based Learning (PBL), and IS skills

\section{INTRODUCTION}

Information Systems (IS) programs are facing challenges so serious that they are threatening the future of IS as an academic discipline. It is very important for IS academics to be aware of these challenges, the implications they have, and the strategies that can be implemented to address them.

In a previous paper [12], the main author presented several important challenges faced by these programs, and proposed two strategies to deal with these challenges. In a second paper [13], the main author presented empirical research on how the first strategy (Project Based Learning) was implemented in a Computer Information Systems program at the University of Puerto Rico including the research methodology, the results obtained, as well as the conclusions and best practices derived from these results.

This paper is the third of a trilogy on how to address some of the challenges currently faced by Information System programs. It proposes a methodology to analyze the skills these programs are developing in students, as well as its application to a particular case in order to determine the need to revise these skills. The results of this analysis should be used to redesign the current program around the desired skills. In the particular case presented in the paper, we will use the methodology to determine if the existing program, designed using projects as the departing point, excluded, over-emphasized, or under-emphasized important skills. That is, we will try to validate through a bottom-up (or skill-based) approach a design originally performed using a top-down (or project-based) approach. But first, we will review the context of this paper through the section that follows.

\section{BACKGROUND AND LITERATURE REVIEW}

\section{Information System Challenges}

The reduction in enrollments is probably the main challenge still faced by IS programs. Several publications have presented and discussed this issue $[8,10]$. There seems to be a turnaround in enrollments lately, but we are still far from the numbers we had in the 90's and early 00's. And if in fact there is a turnaround, we have to promote it so that it does not represent just a small bounce in the enrollment curve. Another important challenge is the perceived lack of relevance of IS programs. "If the people who practice what we teach do not value what we are doing or saying, we will ultimately disappear. [7]" 
Other important challenges are related to the way IS programs are externally perceived. The perception from students, academic advisors and counselors, is that "...only nerdy "non-cool" geeks are involved" in IS [8], and that "We lack the cool factor. ... The technology may be cool, but those who work in it are decidedly not" [15]. Although we cannot fully control perception-related challenges, we can certainly do a lot to influence them.

IS programs also face challenges related to the internals of our programs. Students and employers are asking for a change in the educational strategies we have been using for decades. The traditional approach has been lecture and hands-on laboratories [6]. IS programs may be best served by integrating business functional knowledge and teaching through experiential learning models [1]. And employers are asking for a wider set of skills in our graduates, ranging from functional knowledge to technical skills, and, of course, without leaving out "soft skills", like teamwork, communications ability, ethical values and interpersonal relationships $[3.4,8]$. The good thing about internal challenges is that we can fully control them, even though we still have to comply with institutional restrictions, which may dilute our level of control. And not only we can control them, but by doing this we have a good opportunity to influence other type of challenges, particularly those related to perception [12].

\section{PROPOSED STRATEGIES}

\section{What To Do About These Challenges}

Based on the previous discussion, it is clear that IS programs are facing big challenges and that we must do something about them. While doing this, we must focus on internal challenges, which are the ones over which we have the highest level of control.

In order to tackle internal challenges, we specifically propose two strategies: (1) Using "Project-Based Learning (PBL)" as an educational and assessment strategy, through projects closely resembling those prepared by IS practitioners, and (2) Analyzing the skills that we are currently developing in IS students and revising them around the specific market that we want to serve.

We already addressed the PBL strategy in a previous paper [13], so we will address the skills analysis in this one. Therefore, the main contribution of this paper is to propose a methodology to analyze the skills IS programs are developing in students and to discuss its implementation to a particular case in order to determine the need to revise these skills.

\section{Market to be Served: IT Vendors, IT Clients or Both?}

To implement the skills analysis that we are proposing, we must define which market our program will serve. That is, either the firms providing technological resources (IT vendors), the firms implementing and using those resources (IT clients) or, if feasible, both markets.

To properly define the market our program will serve, several points need to be considered [3]. These points are stated as questions in Table 1.

Table 1. Points to Consider When Defining the Market our Program will Serve

\begin{tabular}{|l|l|}
\hline$\#$ & \multicolumn{1}{|c|}{ Points To Be Considered } \\
\hline 1 & Should we try to prepare programmers as Computer Science programs do? \\
\hline 2 & $\begin{array}{l}\text { Should we try to prepare infrastructure specialists (i.e. LAN managers, technical support specialists) as } \\
\text { Information Technology programs or vendor certifications do? }\end{array}$ \\
\hline 3 & Should we try to prepare business analysts as Accounting or Finance programs do? \\
\hline 4 & $\begin{array}{l}\text { How should we address the competition from big consulting firms, some of which have their own } \\
\text { professional development programs conducted by industry, systems and technical experts? }\end{array}$ \\
\hline 5 & How much should we emphasize systems analysis and project management skills versus technical skills? \\
\hline 6 & How many firms recruit systems analysts and project managers for entry-level positions? \\
\hline 7 & Are we going to survive and grow as a discipline preparing students mostly for non-entry-level positions? \\
\hline
\end{tabular}




\section{AN IMPLEMENTATION OF A SKILLS ANALYSIS METHODOLOGY: THE UPR CASE}

\section{Project-Based versus Skill-Based Approach}

Several years ago, the Computer Information Systems program of the University of Puerto Rico was redesigned around PBL, using projects closely resembling those performed by IS practitioners as the departing point. The reasoning behind using PBL was that meaningful and well-chosen projects should allow students to develop and integrate a comprehensive set of skills, including technical, functional, and soft skills. Besides, when properly defined, projects constitute a reasonably sized building block, feasible to be completed and assessed in one semester courses, and easily aligned to the program's student outcomes, educational objectives and mission. Although skills may be the most logical building block to be used when designing a program, the process could become too detailed, lengthy and difficult to manage. This, because skills are smaller building blocks, larger in number and more detailed in nature, and also because IS programs usually try to develop in students a very wide set of skills.

We followed the top-down methodology presented in Table 2 when originally redesigning our program using the PBL strategy.

Table 2. Top-Down Methodology Used to Implement PBL

\begin{tabular}{|l|l|}
\hline$\#$ & Steps \\
\hline 1 & Identifying typical IS projects \\
\hline 2 & Embedding projects into the curriculum \\
\hline 3 & Creating cases and/or situations related to the projects \\
\hline 4 & Assessing the attainment of student outcomes through the projects \\
\hline 5 & Controlling quality of the process \\
\hline
\end{tabular}

Although the PBL design has been very attractive to students and employers [13], we wanted to make sure that the design we implemented did not exclude, over-emphasize or under-emphasize important skills. In other words, we wanted to validate the PBL design, using skills, instead of projects, as the departing point.

\section{Implementation Methodology}

We followed a bottom-up methodology to implement the skills analysis, consisting of the following seven steps (see Table 3):

Table 3. Bottom-Up Methodology Used to Implement the Skills-Based Analysis

\begin{tabular}{|l|l|}
\hline$\#$ & Steps \\
\hline 1 & $\begin{array}{l}\text { Prepare a comprehensive skills inventory, ranging from client-facing to technical skills, and also including } \\
\text { soft-skills }\end{array}$ \\
\hline 2 & Decide on the specific market the IS program should serve: IT vendors, IT clients, or both \\
\hline 3 & $\begin{array}{l}\text { Perform a mapping between the desired skills for the market to be served and the course projects prepared by } \\
\text { students }\end{array}$ \\
\hline 4 & Identify gaps (skills not addressed, under-addressed or over-addressed) \\
\hline 5 & Modify project contents in order to fill the gaps previously identified \\
\hline 6 & Add and/or delete full projects as needed (which may require adding/deleting courses) \\
\hline 7 & Redesign project assessment rubrics accordingly \\
\hline
\end{tabular}

In our first paper, we proposed to first define which market our program should serve and then prepare a skills inventory for that particular market [12]. But when implementing the strategy, we realized that it was more practical to prepare first a comprehensive skills inventory before deciding on the market to be served, instead of deciding first on the market and then preparing the skills inventory related to that market. Preparing a comprehensive skills inventory with a wide range of computing skills facilitates the decision on which specific market to serve. Consequently, we decided to switch steps one and two. (This change is already reflected in Table 3.) 
Skills inventory. We prepared an inventory of skills ranging from client-facing skills (i.e. Business process analysis, Business process modeling) to the more technical ones (i.e. Programming fundamentals, Infrastructure operations), and also including soft-skills (i.e. Teamwork, Ethics). Professional and academic publications, as well as input from students, alumni, and employers, were important sources of information $[1,3,4,5,6,8]$. Other contributing sources to this process were the input from colleague professors, and the experience of the main author as an IS academic and practitioner. Its structure is based on a product development/procurement, implementation, operation, and administration framework.

The following three-level hierarchical structure was used in order to facilitate the skill identification process:

Major skill categories. Four major skill categories were identified, that closely follow the systems development life-cycle phases: Analysis and Logical Design, Physical Design, Programming, and Systems Implementation. A managerial (IS/IT Management) and an operational category (IS/IT Operations and Maintenance) were included to account for the framework where systems operate in organizations. An additional category for soft skills was included, which gave us a total of seven categories.

Skill sets within categories. The seven major skill categories were subdivided in twenty two skill sets. Some examples of these skill sets are Big Data Analysis, IS/IT Governance, Regulatory, Control and Security Framework, Project Management, Business Process Analysis, Business Process Modeling/Design, Requirements Definition, Systems Procurement, and Systems Deployment.

Specific skills. The twenty two skill sets were in turn divided into 118 specific skills. The approach we followed was to identify the most important skills we would like our students to develop, rather than an exhaustive list of skills that could be developed by an IS program.

As explained above, we prepared an inventory consisting of seven major skill categories, twenty two skill sets and 118 specific categories. Due to space restrictions, only the page for the "IS/IT Management" category is presented in Table 4, together with its four skill sets, its thirty three specific skills, and the corresponding descriptions. A similar table was prepared for each of the other six major skill categories.

Market to be served. After we defined the skills inventory, we tried to define the market our program should serve. While doing this, we kept in mind the degree to which we wanted to stress technical skills, like programming and technical support, or client-facing skills, like systems analysis, process modeling and project management. The questions in Table 1 were taken into consideration. We conducted several faculty meetings to discuss the market to be served by our graduates. We could not agree on a specific market to serve, so we decided to postpone the decision, and continue with the next steps.

Mapping between projects and skills inventory. We performed a mapping between the full skills inventory and our current projects, in order to identify skills under-emphasized, over-emphasized, and not addressed at all. We also prepared a detailed table for each skill set, where we used a scale from 4 to 0 to score the level at which each skill was supported by the projects. Table 5 presents the mapping summarized by skill set and Table 6 presents one example of the mapping for each specific skill within one of the skill sets.

Identify gaps. Based on the individual scores in Table 6, summary figures were calculated to determine the extent to which each project addressed the particular skills within the skill sets (which we called "Horizontal analysis"), as well as the extent to which each particular skill was addressed throughout all projects (which we called "Vertical analysis"). These summarized figures were raised-up to Table 5. Skills under and over emphasized were then identified. 
Projects, rubrics, and courses. Findings were documented based on the level of emphasis calculated for the skill sets in Table 5, and recommendations regarding changes to projects and courses were prepared accordingly.

\section{Findings}

The skills analysis was performed using a rating scale (from 4 to 0 ) combined with a matrix affinity analysis. Findings are presented through tables 5 and 6 , and they are discussed below making reference to those tables.

Table 5. Summarized figures on how skill sets are addressed by each project in each course are presented in Table 5. The rows of the table represent the courses of our program, as well as the projects prepared by students within each course. Columns represent each one of the seven major skill categories we used, together with the twenty two skill sets under these categories. Cells contain the percentage of all the specific skills within each skill set addressed through the projects. For example, $77.8 \%$ of the specific skills under the skill set called "Regulatory, Control and Security Framework" are addressed in the project named "Project to prepare a disaster recovery plan", which is prepared in the course SICI 4275. Looking down the same column we notice that this skill set is also addressed in projects prepared in several other courses, like SICI 4285 (11.1\%), SICI 4286 (11.1\%), and SICI 4405 (5.6\%), although to a lesser extent.

Horizontal analysis. The far right columns ("Number of different skill sets where project is addressed", and "Highest percentage obtained") summarize each project by showing the extent to which the project emphasizes the different skill sets. For example, for the project in course SICI 4275, three skill sets are enabled ("Regulatory, Control and Security Framework", "Ethics", and "Written/Oral Communication"). The highest percentage obtained was 77.8 , belonging to the skill set called "Regulatory, Control and Security Framework". The higher these figures are, the more comprehensive the project has to be in order to be able to enable all those skill sets. But figures too high may represent a problem, because the more comprehensive the project is, the lower the probability that the project can be completed in a one semester course without sacrificing depth.

Vertical analysis. The bottom rows summarize each skill set by showing the extent to which a given skill set is addressed in all projects. The row titled "Number of rows (projects) where skill set is addressed" presents the number of different projects in which the skill set is enabled. For example, the skill set "Regulatory, Control and Security Framework" is addressed in 12 projects, which means it is highly emphasized. Another row at the bottom titled "Highest percentage" shows the highest percentage obtained by the skill set in all the projects in which it is addressed. For the example skill set, this percentage was 77.8. Both numbers show the extent to which a given skill set is addressed in all the projects in the academic program. The higher these figures, the more emphasis the skill set is receiving. Of course, over-emphasis as well as under-emphasis could be a problem. (Dot-shading was used in Table 5 to highlight some of the findings.)

Table 6. The percentages in Table 5 link to more detailed tables, one for each skill set, presenting the scoring analysis performed for each particular skill within the skill set. An example of these detail tables appear in Table 6. In the specific case shown, the skill set is "Regulatory, Control and Security Framework", and there are nine specific skills within this set ("Risk identification, Risk assessment, IS controls, Assessment of existing controls, Recovery measures, Disaster Recovery plan, Regulatory environment, Application controls, and General controls"). A scale from 4 to 0 is used to score the level at which each skill within the skill set is emphasized by the projects. The far right columns summarize each project by showing the extent to which it emphasizes the particular skills within the skill set. The higher these figures are, the more emphasis. For example, the project in SICI 4275 ("Project to prepare a disaster recovery plan") addresses eight of the nine specific skills in the skill set, and the emphasis level is $77.78 \%$ $(=28 / 36)$, which happens to be the percentage raised-up to Table 5, rounded to one decimal place. (See dotshaded cells in Table 6.) Again, over-emphasis as well as under-emphasis may be a problem. 
Issues in Information Systems
Volume 16, Issue III, pp. 80-89, 2015

\begin{tabular}{|c|c|c|c|c|}
\hline \multicolumn{5}{|c|}{$\begin{array}{l}\text { Table 4: Inventory of specific IS/IT skills, within skill sets and major categories (sample page) } \\
\text { IS/IT management category }\end{array}$} \\
\hline$\#$ & & Short title & & Description \\
\hline \multirow[t]{6}{*}{1} & Big D & ata analysis \& decision support(BI) & \multicolumn{2}{|r|}{ Ability to design and create a data warehouse and to use its contents in order to support strategic decision making. } \\
\hline & & Dimensional databases & 1 & Ability to explain the differences between a relational and a dimensional database. \\
\hline & 2 & Data warehouses & 2 & Ability to create a dimensional database to implement a data warehouse to support decision making. \\
\hline & 3 & Data extraction and cleanup (ETL) & 3 & Ability to use tools and techniques to extract data from diferent sources and to improve data quality. \\
\hline & 4 & Data transformation and load (ETL) & 4 & Ability to use tools and techniques to perform data transformation and to populate a dimensional database. \\
\hline & 5 & User interface for decision support & 5 & Ability to create a user interface to allow management to access and analyze data to support decision making. \\
\hline \multirow[t]{9}{*}{2} & IS/IT & governance & \multicolumn{2}{|r|}{$\begin{array}{l}\text { Ability to identify, explain and analyze aspects regarding data center administration, like location, organizational structure, functions, } \\
\text { resources, etc. }\end{array}$} \\
\hline & & Data Center functions & 6 & Ability to identify typical data center functions. \\
\hline & 7 & Data Center location & 7 & Ability to identify usual locations for data centers in organizations. \\
\hline & 8 & Data Center organization & 8 & Ability to identify typical organizational structures for data centers in organizations. \\
\hline & 9 & Centralization vs descentralization & 9 & Ability to evaluate the advantages and disadvantages of centralized versus decentralized data center operations. \\
\hline & 10 & Human resources $\&$ career paths & 10 & Ability to identify the positions and career paths usually found in a data center. \\
\hline & 11 & Cloud computing & 11 & Ability to analyze major considerations of using cloud computing to procure data center services. \\
\hline & 12 & Outsourcing & 12 & Ability to analyze major considerations related to outsourcing data center operations. \\
\hline & 13 & Procurement of IS/IT resources & 13 & Ability to explain the process and considerations to procure IS/IT resources and services for the data center. \\
\hline \multirow[t]{10}{*}{3} & Regul & Llatory, control and security framework & \multicolumn{2}{|r|}{$\begin{array}{l}\text { Ability to explain and analyze regulatory, control and security framework of information systems. Also includes the ability to } \\
\text { implement some control and security measures. }\end{array}$} \\
\hline & & Risk identification & 14 & Ability to identify risks associated to the IS function in an organization. \\
\hline & 15 & Risk assessment & 15 & Ability to evaluate the probability of the occurrence of risks, as well as their impact. \\
\hline & & IS controls & 16 & Ability to identify controls that can reduce the probability of risk occurrence. \\
\hline & 17 & Assessment of existing controls & 17 & Ability to evaluate the effectiveness of existing controls to detect and avoid risks. \\
\hline & 18 & Recovery measures & 18 & Ability to identify measures to recover IS/IT operations when interrupted. \\
\hline & 19 & Disaster recover plans & 19 & $\begin{array}{l}\text { Ability to prepare a disaster recovery plan, consisting of the identification and evaluation of risks, the identification and evaluation of } \\
\text { controls to avoid those risks, and the identification of meassures to recover from interruptions. }\end{array}$ \\
\hline & 20 & Regulatory environment & 20 & Ability to analyze the impact of the regulatory enviroment upon the IS field and IS professionals. \\
\hline & 21 & Application controls & 21 & Ability to identify, design and implement application controls in the design and implementation of systems. \\
\hline & 22 & General controls & 22 & Ability to identify and design general controls, particularly in the design and implementation of technological infrastructure. \\
\hline \multirow[t]{12}{*}{4} & & ect management & \multicolumn{2}{|r|}{ Ability to create a plan to implement an IS project and to control the execution of the plan. } \\
\hline & 23 & Project selection & 23 & Ability to analyze the suitability of several projects to be implemented. \\
\hline & 24 & Scope management & 24 & Ability to identify the tasks that form the scope of a project, as well as their dependencies. \\
\hline & 25 & Time management & 25 & Ability to prepare time estimates for the tasks that compose the scope of a project. \\
\hline & 26 & Cost management & 26 & Ability to prepare cost estimates for the tasks that compose the scope of a project. \\
\hline & 27 & Risk management & 27 & Ability to identify risks related to a project, and to evaluate the probability and impact of each one of them. \\
\hline & 28 & Quality management & 28 & Ability to identify quality measures for the deliverables, as well as the processess, of a project. \\
\hline & $29+1$ & Human resources management & 29 & Ability to identify the human resources necessary to perform the tasks in a project. \\
\hline & 30 & Procurement management & 30 & $\begin{array}{l}\text { Ability to analyze when to use vendors to procure project resources and to identify measures to control the performance of these vendors } \\
\text { in the project. }\end{array}$ \\
\hline & 31 | 1 & Integration management & 31 & Ability to integrate all tasks involved in a project into a comprehensive project plan. \\
\hline & 32 & Project management tools & 32 & Ability to use a project managemnet tool to prepare and control the project plan. \\
\hline & 33 & Resistance to change & 33 & Ability to identify the factors that provoke resistance to change and ways to deal with them. \\
\hline
\end{tabular}




\section{Issues in Information Systems \\ Volume 16, Issue III, pp. 80-89, 2015}






\begin{tabular}{|c|c|c|c|c|c|c|c|c|c|c|c|c|c|c|c|}
\hline & \multicolumn{12}{|c|}{ Regulatory, control and security framework } & \multicolumn{2}{|c|}{ H. analysis } & \multirow{2}{*}{$\begin{array}{c}\text { REMARKS } \\
\text { Remarks regarding skills } \\
\text { addressed in each project }\end{array}$} \\
\hline Courses/Projects &  & 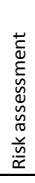 & $\begin{array}{l}\stackrel{0}{0} \\
0 \\
0 \\
\underline{0} \\
\underline{0}\end{array}$ & 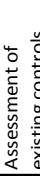 & 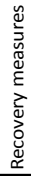 & 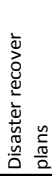 & 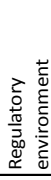 & 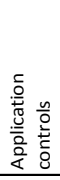 & 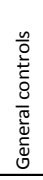 & & & & 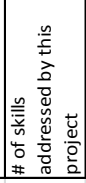 & 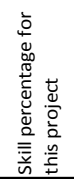 & \\
\hline \multicolumn{16}{|l|}{ SICI 3211: } \\
\hline Basic project on systems & & & & & & & & & & & & & & & \\
\hline design and implementation & 0 & 0 & 0 & 0 & 0 & 0 & 0 & 0 & 0 & & & & 0 & $0.00 \%$ & \\
\hline \multicolumn{16}{|l|}{ SICI 3245: } \\
\hline \begin{tabular}{|l} 
Design of a technological \\
infrastructure for an IS
\end{tabular} & 0 & 0 & 0 & 0 & 0 & 0 & 0 & 0 & 2 & & & & 1 & $5.56 \%$ & \\
\hline \multicolumn{16}{|l|}{ SICI 3255: } \\
\hline $\begin{array}{l}\text { Comprehensive } \\
\text { programming project }\end{array}$ & 0 & 0 & 0 & 0 & 0 & 0 & 0 & 2 & 0 & & & & 1 & $5.56 \%$ & \\
\hline \multicolumn{16}{|l|}{ SICI 4015: } \\
\hline \begin{tabular}{|l|} 
Design and implementation \\
of an IS using a DBMS
\end{tabular} & 0 & 0 & 0 & 0 & 0 & 0 & 0 & 3 & 0 & & & & 1 & $8.33 \%$ & \\
\hline \multicolumn{16}{|l|}{ SICI 4025: } \\
\hline \begin{tabular}{|l} 
Project to define \\
requirements for an IS
\end{tabular} & 0 & 0 & 0 & 0 & 0 & 0 & 0 & 0 & 0 & & & & 0 & $0.00 \%$ & \\
\hline \multicolumn{16}{|l|}{ SICI 4266: } \\
\hline $\begin{array}{l}\text { Design and implementation } \\
\text { of an web application }\end{array}$ & 0 & 0 & 0 & 0 & 0 & 0 & 0 & 2 & 0 & & & & 1 & $5.56 \%$ & \\
\hline \begin{tabular}{|l|}
$\begin{array}{l}\text { Design and implementation } \\
\text { of a desktop application }\end{array}$ \\
\end{tabular} & 0 & 0 & 0 & 0 & 0 & 0 & 0 & 2 & 0 & & & & 1 & $5.56 \%$ & \\
\hline \multicolumn{16}{|l|}{ SICI 4275: } \\
\hline \begin{tabular}{|l|} 
Project to prepare a disaster \\
recovery plan
\end{tabular} & 4 & 4 & 4 & 4 & 4 & 4 & 2 & 0 & 2 & & & & 8 & $7.2 .8 \%$ & $\begin{array}{l}\text { Skills in this category mostly } \\
\text { addressed by this project. }\end{array}$ \\
\hline \multicolumn{16}{|l|}{ SICI 4278: } \\
\hline $\begin{array}{l}\text { Short essay on professional// } \\
\text { IS environment issues }\end{array}$ & 0 & 0 & 0 & 0 & 0 & 0 & 0 & 0 & 0 & & & & 0 & $0.00 \%$ & \\
\hline $\begin{array}{l}\begin{array}{l}\text { Plan to implement an } \\
\text { information system }\end{array} \\
\end{array}$ & 0 & 0 & 0 & 0 & 0 & 0 & 0 & 0 & 0 & & & & 0 & $0.00 \%$ & \\
\hline \multicolumn{16}{|l|}{ SICI 4285: } \\
\hline \begin{tabular}{|l} 
Design of a wide area \\
network to support an IS
\end{tabular} & 0 & 0 & 0 & 0 & 0 & 0 & 0 & 0 & 4 & & & & 1 & $11.11 \%$ & \\
\hline \multicolumn{16}{|l|}{ SICI 4286: } \\
\hline \begin{tabular}{|l} 
Design of a local area \\
network to support an IS
\end{tabular} & 0 & 0 & 0 & 0 & 0 & 0 & 0 & 0 & 4 & & & & 1 & $11.11 \%$ & \\
\hline \multicolumn{16}{|l|}{ SICI 4405: } \\
\hline $\begin{array}{l}\text { Design and implementation } \\
\text { of an ecommerce system }\end{array}$ & 0 & 0 & 0 & 0 & 0 & 0 & 0 & 2 & 0 & & & & 1 & $5.56 \%$ & \\
\hline \multicolumn{16}{|l|}{ SICI 4465: } \\
\hline $\begin{array}{l}\text { Research paper on legal } \\
\text { issues of computer }\end{array}$ & 0 & 0 & 0 & 0 & 0 & 0 & 4 & 0 & 0 & & & & 1 & $11.11 \%$ & \\
\hline \multicolumn{16}{|l|}{ SICI 4998: } \\
\hline $\begin{array}{l}\text { Short essay on ethical } \\
\text { values/interpersonal }\end{array}$ & 0 & 0 & 0 & 0 & 0 & 0 & 0 & 0 & 0 & & & & 0 & $0.00 \%$ & \\
\hline \multicolumn{16}{|l|}{ SICI 4215: } \\
\hline $\begin{array}{l}\text { Design/implementation of a } \\
\text { data warehouse to support } \mathrm{a}\end{array}$ & 0 & 0 & 0 & 0 & 0 & 0 & 0 & 3 & 0 & & & & 1 & $8.33 \%$ & \\
\hline \multicolumn{16}{|l|}{ SICI 5250: } \\
\hline \begin{tabular}{|l|}
$\begin{array}{l}\text { Design and implementation } \\
\text { of an ERP system }\end{array}$ \\
\end{tabular} & 0 & 0 & 0 & 0 & 0 & 0 & 0 & 3 & 0 & & & & 1 & $8.33 \%$ & \\
\hline \multicolumn{16}{|l|}{ VERTICAL ANALYSIS: } \\
\hline $\begin{array}{l}\text { Number of rows (projects) } \\
\text { where skill is addressed }\end{array}$ & 1 & 1 & 1 & 1 & 1 & 1 & 2 & 7 & 4 & 0 & 0 & 0 & $\mathrm{~N} / \mathrm{A}$ & $\mathrm{N} / \mathrm{A}$ & \\
\hline Highest individual score for skill & 4 & 4 & 4 & 4 & 4 & 4 & 4 & 3 & 4 & 0 & 0 & 0 & N/A & N/A & \\
\hline
\end{tabular}




\section{DISCUSSION, CONCLUSIONS AND RECOMMENDATIONS}

The way we structured the skill-based analysis facilitates identifying findings, particularly by examining the rightmost columns (horizontal analysis columns) and the bottom rows (vertical analysis rows) in tables 5 and 6 . There are several findings worth mentioning, but we want to emphasize five of them (see Table 7), for which we have also included recommendations. (You may want to refer to the dot-shaded cells at the bottom of Table 5, right below the label "Vertical Analysis".)

Table 7. Main Findings and Recommendations

\begin{tabular}{|c|c|c|c|}
\hline$\#$ & Finding Description & \# & Recommendations \\
\hline 1 & $\begin{array}{l}\text { The skill set "Regulatory, Control and } \\
\text { Security Framework" is addressed in a high } \\
\text { number of projects (twelve), although only in } \\
\text { one of them (SICI 4275) it is highly } \\
\text { emphasized }(77.8 \%) \text {. }\end{array}$ & 1 & $\begin{array}{l}\text { Since only one of the twelve projects addresses this skill } \\
\text { set at a level higher than } 11.1 \% \text { no actions are } \\
\text { recommended for this finding at this time. }\end{array}$ \\
\hline 2 & $\begin{array}{l}\text { There are two important skill sets not } \\
\text { addressed or barely addressed, which are: } \\
\text { "Systems Procurement/Sourcing", and } \\
\text { "Applications Maintenance". But, although } \\
\text { "Application Maintenance" is not directly } \\
\text { addressed, it gets addressed indirectly } \\
\text { through the following two other skill sets: } \\
\text { "Programming System Components", and } \\
\text { "Programming Fundamentals". }\end{array}$ & 2 & $\begin{array}{l}\text { Create a course on "IS Governance, and IS Resource } \\
\text { Procurement", including Systems Evaluation and } \\
\text { Selection. It may also include Infrastructure operations, } \\
\text { Applications maintenance, and User support. It could be } \\
\text { titled "IS Strategy, Procurement and Governance" to be } \\
\text { in agreement with IS 2010, and to emphasize the } \\
\text { strategic side of IS [2]. }\end{array}$ \\
\hline 3 & $\begin{array}{l}\text { The skill category "IS Operations and } \\
\text { Maintenance" may need to receive more } \\
\text { emphasis. Most of its skills, except for } \\
\text { "Database Administration", are addressed in } \\
\text { only one project, and the addressing } \\
\text { percentages are low }(<17 \%) \text {. }\end{array}$ & 3 & $\begin{array}{l}\text { Enable the skills under "Infrastructure Operations and } \\
\text { Maintenance" as part of courses SICI } 3245 \text {, and/or SICI } \\
4285 / 4286 \text {, and make sure the corresponding projects in } \\
\text { these courses address this skill set. Also, the new course } \\
\text { being proposed on "IS Strategy, Procurement and } \\
\text { Governance" may address some of these skills. }\end{array}$ \\
\hline 4 & $\begin{array}{l}\text { Some specific skills within their respective } \\
\text { skill sets need to be reinforced, like Web } \\
\text { services, Software installation, and Mobile } \\
\text { applications (not shown in the tables } \\
\text { included due to lack of space!) }\end{array}$ & 4 & $\begin{array}{l}\text { Include Web services and Mobile Applications in one of } \\
\text { the projects prepared in SICI 4266, for example by } \\
\text { substituting one of the current topics, like "Desktop } \\
\text { Application Development". }\end{array}$ \\
\hline 5 & $\begin{array}{l}\text { Physical System Design skill set seems to be } \\
\text { overemphasized, as it is enabled in at least } \\
50 \% \text { in four different projects (SICI 4015, } \\
\text { SICI } 4266 \text { ( } 2 \text { projects), SICI 4215). }\end{array}$ & 5 & $\begin{array}{l}\text { Reduce emphasis on Physical Systems Design and } \\
\text { increasing emphasis on Systems Procurement through a } \\
\text { course on "IS Strategy, Procurement and Governance", } \\
\text { as per the first recommendation. }\end{array}$ \\
\hline
\end{tabular}

As stated by the second finding, of all the skill sets in the inventory, the most noticeable missing one is "Systems Procurement/Sourcing", which belongs to the "Systems Implementation" category. The reason for this probably was that when we were redesigning our program around PBL we missed to identify a project related to those skills, which in turn may have been because we tended to emphasize systems development over systems procurement. The skill-based analysis clearly shows this situation.

The skills-based analysis we have implemented has proven to be very convenient for reviewing our IS program design and validating the implementation of our PBL strategy. Among other things, it has allowed us to identify gaps in addressing some skill sets, as well as to determine the extent to which several skill sets are addressed. This 
information has already been used to revise our program. As originally stated, the continuous analysis and revision of the skills addressed by an IS program is a good way to address IS program challenges, particularly those related to perception, relevance, and enrollments $[3,4,8]$.

\section{NOTES}

In this paper we are using the term "skill" in a very broad sense, covering the knowledge about something, the capability to do it, and the level of efficiency doing it. That is, very closely related to the term "competency".

\section{REFERENCES}

1. Abraham, Thomas; Beath, Cynthia; Bullen, Christine; Gallagher, Kevin; Goles, Tim; Kaiser, Kate; and Simon, Judith (2006). "IT Workforce Trends: Implications For IS Programs", Communications of the Association for Information Systems: Vol. 17, Article 50. Available at: http://aisel.aisnet.org/cais/vol17/iss1/50

2. ACM and AIS (2010). IS 2010: Curriculum Guidelines for Undergraduate Degree Programs in Information Systems. Available at http://www.acm.org/education/curricula

3. Bullen, Christine V.; Abraham, Thomas; Gallagher, Kevin; Simon, Judith C.; and Zwieg, Phil (2009). "IT Workforce Trends: Implications for Curriculum and Hiring", Communications of the Association for Information Systems, Volume 24, Article 9, pp. 129-140, January 2009, Retrieved from http://aisel.aisnet.org

4. Firth, David; King, John; Koch, Hope; Looney, Clayton Arlen; Pavlou, Paul; and Trauth, Eileen M. (2011) "Addressing the Credibility Crisis in IS," Communications of the Association for Information Systems: Vol. 28, Article 13. Available at: http://aisel.aisnet.org/cais/vol28/iss1/13

5. Future of Computing in Education Position Papers (2009). Association for Computing Machinery. Available at http://www.acm.org/education/future-of-computing-education-summit/position-papers/Comptia.pdf

6. Future of Computing in Education Summit (2009). Association for Computing Machinery. Available at http://www.acm.org/education/future-of-computing-education-summit

7. Ginzberg, Michael J. (2012). A Business Dean's Perspective on the IS Field, The DATA BASE for Advances in Information Systems, Volume 43, Number 2, May 2012.

8. Granger, Mary J.; Dick, Geoffrey; Luftman, Jerry; Van Slyke, Craig; and Watson, Richard T. (2007). Information Systems Enrollments: Can They Be Increased?, Communications of the Association for Information Systems: Vol. 20, Article 41. Available at: http://aisel.aisnet.org/cais/vol20/iss1/41

9. Gray, Paul. (2012). The Other? The DATA BASE for Advances in Information Systems Volume 43, Number 2, May 2012

10. Koch, Hope; Van Slyke, Craig; Watson, Rick; Wells, John; and Wilson, Rick (2010). Best Practices for Increasing IS Enrollment: A Program Perspective Communications of the Association for Information Systems: Vol. 26, Article 22. Available at: http://aisel.aisnet.org/cais/vol26/iss1/22

11. Laudon, K (2011). Occupational and Career Outlook for MIS Majors 2012-2018, Creative Commons, New York University Stern School of Business.

12. Ramos-Torres, A. (2013). Current IS Program Challenges and Proposed Strategies to Address Them. Issues in Information Systems, 14(2), 101-108.

13. Ramos-Torres, A. (2014). Experiential Learning to Make Information Systems Programs More Responsive to Student and Industry Needs. Issues in Information Systems, 15(1), 88-97.

14. Tamniru, Mohan (2012). Should IS Departments Have a Strong Presence in the Business School? The DATA BASE for Advances in Information Systems Volume 43, Number 2, May 2012. 